\title{
繰り返し載荷を受ける伝統木造仕口の弾塑性解析 \\ ELASTO-PLASTIC ANALYSIS OF JOINTS IN TRADITIONAL TIMBER FRAMES SUBJECTED TO CYCLIC LOADING
}

\author{
栘井 健*，菅沼信明** \\ Takeshi MASUI and Nobuaki SUGANUMA
}

\begin{abstract}
We propose an incremental displacement analysis method for joints in traditional timber frames subjected to cyclic loading. We introduce a method of incorporating the constitutive law of Coulomb's friction for the shear spring directly into the stiffness equation. We carried out an incremental displacement analysis based on the proposed method, and performed a simulation of the results of a loading experiment. We compared the experimental and analysis results, and confirmed that the shapes of the hysteresis loops for strength and stiffness were generally consistent. We confirmed the high validity and efficiency of the proposed analysis method.
\end{abstract}

Keywords : Traditional timber frame, J oint, Compressive strain inclined to grain, F riction, Elasto-plastic analysis, Cyclic loading 伝統木造軸組, 仕口, めり込み, 摩擦, 弾塑性解析, 繰り返し載荷

\section{1. はじめに}

伝統木造軸組構法では、水平抵抗の多くを仕口におけるモーメン 卜抵抗が負担している。そのため、伝統木造軸組の水平抵抗性能を 把握するためには、仕口の構造特性を適切に評価する必要がある。 仕口の構造特性を評価することを目的として、これまで数多くの解 析的研究が実施されている。

船坂、西村 1 は、仕口部を仮想剛体と仮想ばねで表し、木材の局 部変形による剛性変化、木材間の摩擦抵抗、込栓の抵抗を簡易に評 価するための力学モデルを提案した。森迫ら ${ }^{2}$ は柱 - 貫仕口部試験 体について繰り返し載荷実験を行い、その復元力特性をモデル化し た。李ら ${ }^{3)}$ は柱と貫の相対回転角に応じためり込み特性に関する実 験からめり込み構成則のモデル化を行い、得られた構成則を用いて 柱 - 貫接合部の復元力特性を予測する手法を定式化した。

骨組が繰り返し載荷を受ける場合は、木材の接触と離間やめり込 みによる木材の塑性変形が累積される。従って、繰り返し載荷時の 履歴特性を簡便かつ適切に評価できる仕口のモデル化及び解析法の 確立が重要である。錦田ら 4 ${ }^{4}$ は、仕口内部のめり込み特性を弾塑性 ばねで置換した解析モデルを構築し、木造軸組の繰り返し載荷時の 履歷特性を評価した。著者ら 5 ) は仕口内部の接触面における抵抗要 素を、接触面に対して垂直方向はめり込みによる抵抗、平行方向は 滑りを伴う摩擦抵抗と滑りを伴わない抵抗に分解して考えた解析モ デルを構築し、それに基づく新たな解析法を提案した。めり込みに
よる抵抗については材料試験から得られる材料特性を用いて評価し、 平行方向の抵抗については、クーロン摩擦の構成則に基づいたみか けのせん断剛性の概念を導入した。

しかし、この解析法 5)では、みかけのせん断剛性を導出するため には、繰り返し収束計算を必要とした。このため、複雑な仕口形状 を取り扱うような場合では接触面の数が多くなり、ばねモデルの数 が増加し、繰り返し収束計算回数が増大寸ることとなる。

そこで本論文では、上記の問題を解決するために、文献 5) と同じ 解析モデルを用いるが、繰り返し収束計算を必要としない変位増分 解析法を提案する。接触面に対して平行方向の抵抗については、ク 一ロン摩擦の構成則を直接剛性方程式に組み込む方法を新たに導入 する。また、解析法の妥当性を示すために 2 つの形式の伝統木造仕 口を対象とした繰り返し載荷実験のシミュレーションを行う。なお、 本論文の一部は既に文献 6)で報告している。

\section{2. クーロン摩擦の構成則を直接剛性方程式に組み込んだ弾塑性解 析法}

2. 1 クーロンスライダー付きばねモデル

文献 5)において導入された解析モデルについて、その概要を以下 にまとめる。

仕口にモーメント荷重が作用すると Fig.1(a)に示すように、内部 では接触面・非接触面が発生する。文献 5)では仕口内部の接触面に
* 関西大学環境都市工学部建築学科 教授・博士 (工学)

** 関西大学大学院理工学研究科 大学院生
Prof., Dept. of Architecture, Faculty of Environmental and Urban Eng., Kansai Univ., Dr.Eng. Grad. Student, Graduate School of Science and Engineering, Kansai Univ. 
おける抵抗要素を、接触面に対して垂直方向と平行方向に分解して 考えた。仕口の解析モデルの構築に際して、次の仮定を設けた。

- 主材 (梁、柱) 同士の接触面の位置は材軸線に関して分けられ るものとする。

・ めり込多性状は文献 7)のめり込み性状で表される。ほぞや貫及 び胴付き接触面におけるめり込みは三角形変位めり込み、込栓及 び鼻栓接触面におけるめり込みは等変位めり込みとする。

- 同一樹種の木材同士が接触する面の場合、繊維直交方向のめり 込みのみを考慮し、繊維方向のめり込みは考慮しない。

・ 込栓、鼻栓のように、剛性が異なる木材が接触する面の場合、 剛性が低いほうの木材のめり込みのみを考慮する。

・ 接触面に対して平行方向の抵抗は、ほぞや貫及び胴付き接触面 のみを考慮し、込栓及び鼻栓接触面は考慮しない。また、ほぞや 貫の幅方向における摩擦抵抗は考慮しない。(Fig.1(b))

・ めり込夕による抵抗は接触面に設ける弾塑性ばねで表現する。 弾塑性ばねは圧縮側のみに作用し引張側には作用しない。

・ 仕口内部の初期クリアランスは、めり込みを表現した弾塑性ば ねに初期伸びを与えることで表現寸る。また、楔の打ち込み等に よる初期応力は、弾塑性ばねに初期縮みとそれに対応する初期ば ね力を与えることで表現する。

想定される接触面で発生しうるめり込みによる圧縮応力度分布を Fig. 2 に示す。ほぞ及び貫接触面における三角形分布応力度及び余 長部 7)の応力度と、込栓接触面における等分布応力度を想定する。 圧縮応力度分布は集中力にそれぞれ置き換えられる。その作用位置 は、ほぞ及び貫接触面では余長部を除く加圧面下の三角形分布応力 度の合力作用点とし、込栓接触面では等分布応力度の合力作用点と する。合力作用点に弾塑性ばねを配置し、これをめり込みばねと称 する。込栓接触面ではめり込みばねを単独で配置する。めり込みば ねの伸びは合力作用点でのめり込み量とする。

接触面に対して平行方向の抵抗については、滑りを伴う摩擦抵抗 と、滑りを伴わない抵抗に分解してモデル化をする。摩擦抵抗はク ーロンスライダー、滑りを伴わない抵抗はせん断弾性ばねで表現し、 直列結合する。これをせん断ばねと称する。さらに接触面上に配置 してめり込みばねと連結する。Fig. 3 に接触面の抵抗要素を表現し たばねモデルを示寸。以降、これをクーロンスライダー付きばねモ デルと称することとする。

\section{2 仕口の剛性方程式}

仕口形状に応じて、単独で用いるめり込みばねとクーロンスライ ダー付きばねモデルを適切に配置する。それらを剛棒で連結し、仕 口をモデル化する。これを剛体 - ばねモデルと称する。

仕口の剛体 - ばねモデルについて、変位を代表する節点の節点力 速度ベクトルを $\dot{\mathbf{p}}$ 、節点変位速度ベクトルを $\mathbf{u}$ と表す。ばねの配置 点における変位速度ベクトルを六、ばね力速度ベクトルを $\mathbf{f}$ と表す。 ここに、(・) は諸状態量の経路パラメータに対する変化率を意味す る。

$\dot{\mathbf{x}}$ と $\mathbf{u}$ の関係は次式のように表される。

$$
\dot{\mathbf{x}}=\mathbf{D u}, \quad \dot{\mathbf{x}}=\left\{\begin{array}{lllllllll}
\dot{x}_{\mathrm{el}} & \cdots & \dot{\mathrm{x}}_{\mathrm{em}} & \dot{\mathrm{x}}_{\mathrm{cl}} & \cdots & \dot{\mathrm{x}}_{\mathrm{cn}} & \dot{\mathrm{x}}_{q 1} & \cdots & \dot{\mathrm{x}}_{q \mathrm{n}}
\end{array}\right\}^{\mathrm{T}}
$$

ここに、D は節点とばねモデルの配置点の位置関係より定まる係数 行列である。添字の e は単独で用いるめり込みばね、c はクーロン スライダー付きばねモデルにおけるめり込みばね、 $q$ はせん断ばね
を示す。また $\mathrm{m}$ は単独で用いるめり込みばねの個数、nはクーロ ンスライダー付きばねモデルの個数である。

$\dot{\mathbf{p}}$ と白 は反傾則より、次式のように表される。

$$
\dot{\mathbf{p}}=\mathbf{D}^{\mathrm{T}} \dot{\mathbf{f}}, \quad \dot{\mathbf{f}}=\left\{\begin{array}{lllllllll}
\dot{f}_{\mathrm{el}} & \cdots & \dot{\mathrm{f}}_{\mathrm{em}} & \dot{\mathrm{f}}_{\mathrm{cl}} & \cdots & \dot{\mathrm{f}}_{\mathrm{cn}} & \dot{\mathrm{f}}_{\mathrm{q} 1} & \cdots & \dot{\mathrm{f}}_{\mathrm{qn}}
\end{array}\right\}^{\mathrm{T}}
$$

$\dot{\mathbf{f}}$ と $\dot{\mathbf{x}}$ の関係は、フックの法則より次式のように表される。
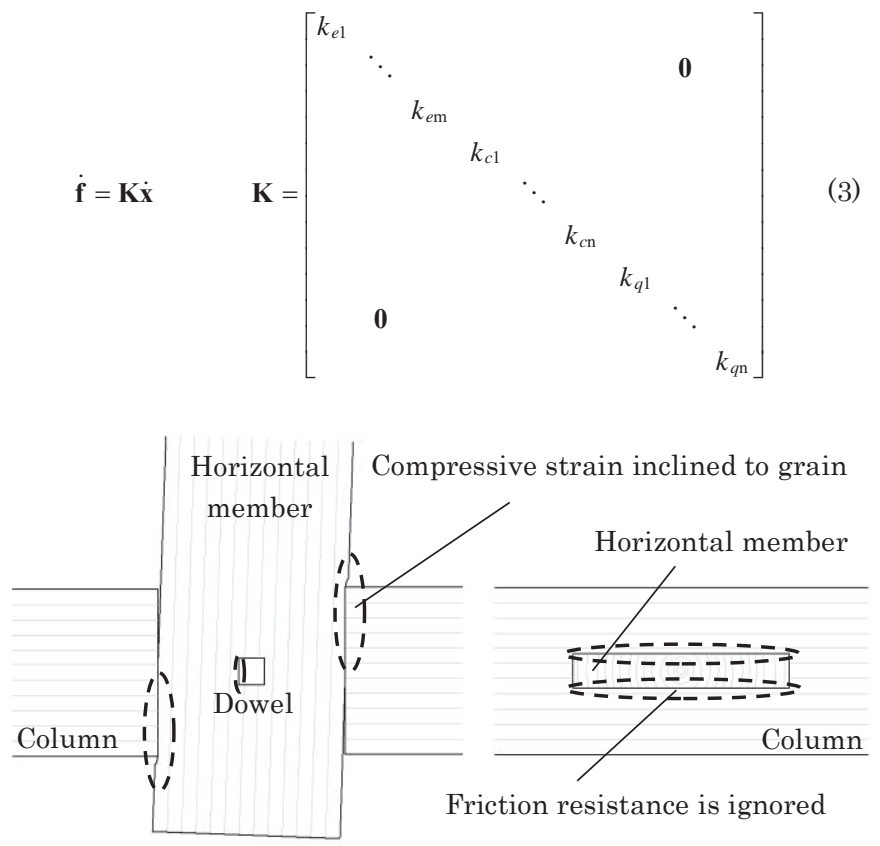

(a) Section

(b) Top view

Fig. 1 Characteristic of compressive strain inclined to the grain

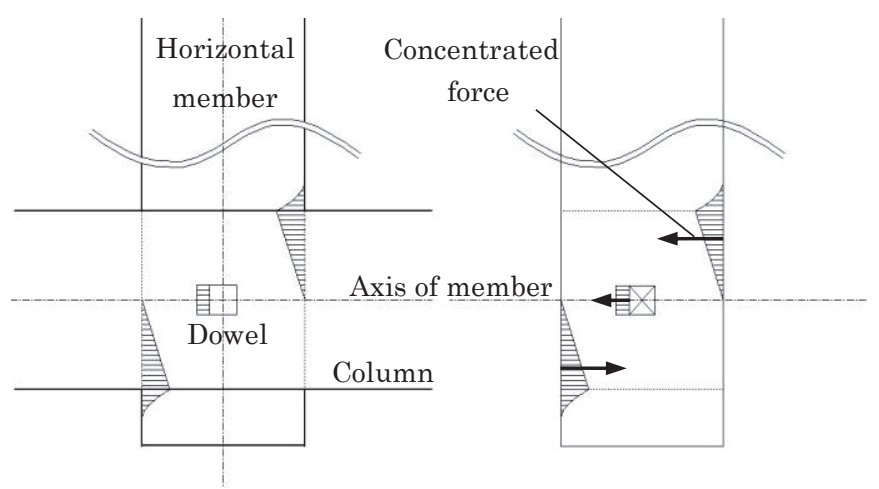

Fig. 2 Compressive stress distribution and concentrated forces

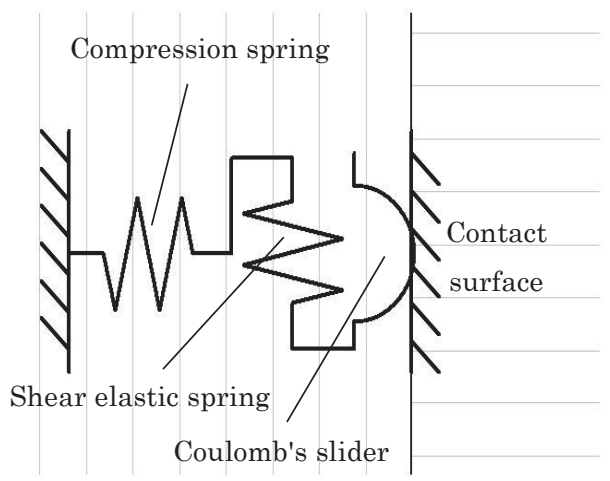

Fig. 3 Spring model with Coulomb's slider 
ここに、Kはめり込みばね及びせん断ばねの剛性に関する剛性行列 である。 k $\mathrm{e}$ は単独で用いるめり込みばねの剛性、 k $\mathrm{c}$ はクーロンス ライダー付きばねモデルにおけるめり込みばねの剛性、 $\mathrm{kq}$ はせん断 ばねの剛性である。

式(1)〜(3)より、仕口の剛体 - ばねモデルにおける速度型の剛性方 程式は次式のように表される。

\section{$\mathbf{p}=\mathbf{D}^{\top} \mathbf{K D u}$}

(4)

\section{3 めり込みばねの構成則 ${ }^{5}$}

めり込みばねの構成則 $\left(\mathrm{k}_{\mathrm{c}}, \mathrm{k}_{\mathrm{e}}\right)$ を Fig.4 に示す。めり込みばね特 性はスリップバイリニア型とし、ばねの伸びXc は圧縮を負とする。 めり込みばねは圧縮側のみに作用し引張側には作用しない。弾性域、 除荷過程をばね状態 I 、塑性域をばね状態 II 、木材の離間過程をば 壮状態 III とする。第 1 剛性 $\mathrm{k} 1$ はめり込み理論 8)に基づいて求める。 等変位めり込みの場合は等変位めり込夕基準式により求める。三角 形変位めり込みの場合はモーメント一変形角関係により求める。第 2 剛性は第 1 剛性の $\alpha$ 倍とする。降伏縮みは $\mathrm{X}_{\mathrm{cy}}$ 、降伏ばね力は $\mathrm{f}_{\mathrm{cy}}$ 、 残留縮みは $\mathrm{X}_{\mathrm{cr}}$ と表す。ばね状態ごとのめり込みばねのばね力 $\mathrm{f}_{\mathrm{c}}$ と 伸び $X_{c}$ の関係式を以下に示す。

・弾性域、除荷過程（ばね状態 I)

$$
\mathrm{f}_{\mathrm{c}}=\mathrm{k}_{\mathrm{l}}\left(\mathrm{x}_{\mathrm{c}}-\mathrm{x}_{\mathrm{cr}}\right)
$$

・塑性域（ばね状態 II）

$$
\mathrm{f}_{\mathrm{c}}=\alpha \mathrm{k}_{1}\left(\mathrm{x}_{\mathrm{c}}-\mathrm{x}_{\mathrm{cy}}\right)+\mathrm{f}_{\mathrm{cy}}
$$

・離間過程（ばね状態III）

\section{4 せん断ばねの構成則 ${ }^{5)}$}

$$
f_{c}=0, \quad x_{c} \geq x_{c r}
$$

せん断ばねの構成則を Fig.5 に示す。2.1 節で述べたように、せん 断ばねはクーロンスライダーとせん断弾性ばねの直列結合であるか ら、その構成則はめり込みばねのばね力 $\mathrm{f}_{\mathrm{c}}$ が一定のとき完全弾塑性 型となる。せん断弾性ばねの剛性を $\mathrm{k}_{\mathrm{s}}$ とすると、せん断ばねの剛性 $\mathrm{k}_{\mathrm{q}}$ は弾性域では $\mathrm{k}_{\mathrm{q}}=\mathrm{k}_{\mathrm{s}}$ となる。せん断ばねのばね力 $\mathrm{f}_{\mathrm{q}}$ は圧縮を負 とし、 $\mathrm{f}_{\mathrm{c}}<0$ のときのみ作用する。摩擦係数を $\mu$ とし、せん断ばね のばね力 $f_{q}$ と伸び $x_{q}$ の関係式を以下に示す。

$$
\begin{gathered}
\dot{\mathrm{f}}_{\mathrm{q}}=0, \quad \begin{cases}\text { if } & \mathrm{f}_{\mathrm{q}}=-\mu \mathrm{f}_{\mathrm{c}} \text { and } \dot{x}_{\mathrm{q}} \geq 0 \\
\text { if } & \mathrm{f}_{\mathrm{q}}=\mu \mathrm{f}_{\mathrm{c}} \text { and } \dot{\mathrm{x}}_{\mathrm{q}} \leq 0\end{cases} \\
\mathrm{f}_{\mathrm{q}}=\mathrm{k}_{\mathrm{s}} \dot{x}_{\mathrm{q}}, \quad \begin{cases}\text { if } & \left|\mathrm{f}_{\mathrm{q}}\right|<\left|\mu \mathrm{f}_{\mathrm{c}}\right| \\
\text { if } & \mathrm{f}_{\mathrm{q}}=-\mu \mathrm{f}_{\mathrm{c}} \text { and } \dot{x}_{\mathrm{q}}<0 \\
\text { if } & \mathrm{f}_{\mathrm{q}}=\mu \mathrm{f}_{\mathrm{c}} \text { and } \dot{\mathrm{x}}_{\mathrm{q}}>0\end{cases}
\end{gathered}
$$

\section{5 クーロン摩擦の構成則を直接組み込んだ剛性方程式}

仕口が変形すると、めり込みばねのばね力 $\mathrm{f}_{\mathrm{c}}$ は変動するため、最 大摩擦力 $\mu \mathrm{f}_{\mathrm{c}}$ も変動する。変動する $\mathrm{f}_{\mathrm{c}}$ に対しても、せん断ばねはそ の構成則を満たす必要がある。仕口の変形に伴って、せん断ばねが クーロン摩擦の構成則を満たし続けるならば、せん断ばねのばね力 速度に関して、次式が成り立たなければならないこととなる。

$$
\mathrm{f}_{\mathrm{q}}=\mu \hat{f}_{\mathrm{c}}
$$

本来、 $\mathrm{f}_{\mathrm{q}}$ 及び $\dot{f}_{\mathrm{c}}$ は独立した変数であるため、この関係は一般に は成立しない。この問題を解決するために文献 5)ではせん断弾性ば ねの伸びとクーロンスライダーの滑りを合成したものに関するみか けのせん断剛性の概念を導入した。みかけのせん断剛性の概念図を
Fig.6 に示す。せん断ばねの状態が点 $P\left(x_{q}, f_{q}\right)$ にあり、 $f_{q}=\mu f_{c}$ を 満たしている場合を考える。仕口の変形に伴って、せん断ばねがク 一ロン摩擦の構成則を満たし続けるとき、せん断ばねはせん断弾性 ばねが縮む過程 PQ とクーロンスライダーが滑る過程 QR が同時に 生じて経路 PR を辿ると仮定し、経路 PR の傾きをみかけのせん断 剛性 $k_{a}$ として定義した。滑りが発生する場合におけるせん断ばねの ばね力速度 - 伸び速度関係は次式のように表される。

$$
\begin{aligned}
\mathrm{f}_{\mathrm{q}} & =\mathrm{k}_{\mathrm{a}} \dot{X}_{\mathrm{q}} \\
\mathrm{k}_{\mathrm{a}} & =\mu \dot{\mathrm{f}}_{\mathrm{c}} / \dot{\mathrm{X}}_{\mathrm{q}}
\end{aligned}
$$

式(12)からみかけのせん断剛性 $\mathrm{k}_{\mathrm{a}}$ はせん断弾性ばねの剛性 $\mathrm{k}_{\mathrm{s}}$ に 依存しないことが確認できる。

しかし、この解析法 5)では、みかけのせん断剛性を導出するため には、繰り返し収束計算を必要とした。このため、複雑な仕口形状 を取り扱うような場合では接触面の数が多くなり、ばねモデルの数 が増加し、繰り返し収束計算回数が増大寸ることとなる。

そこで本論文では新たにクーロン摩擦の構成則を直接剛性方程式 に組み込む方法を導入する。本来、せん断ばねのばね力速度に関し て、式(9)が成立する。しかし、仕口の変形に伴って、せん断ばねが クーロン摩擦の構成則を満たし続ける場合、式(9)は成立せず、式 (10)を満たさなければならない。これらの関係から、せん断ばねの ばね力速度に関して、次式のように表す。

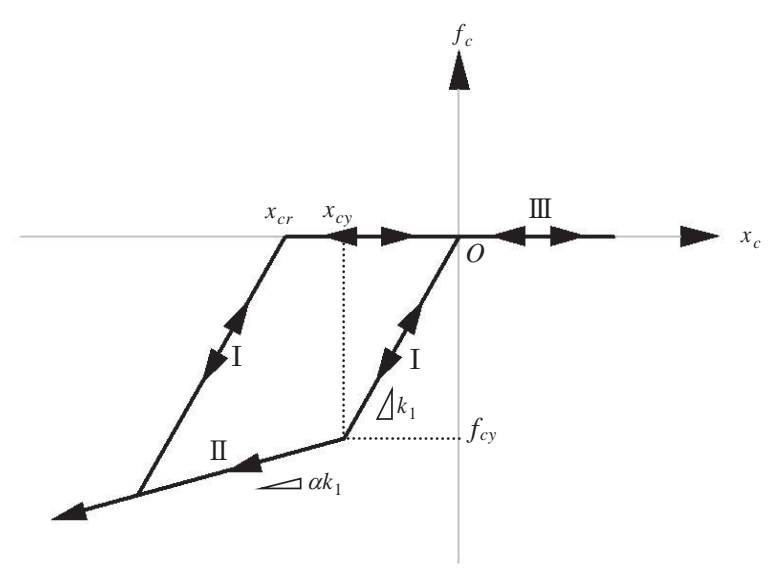

Fig. 4 Constitutive law of compression spring

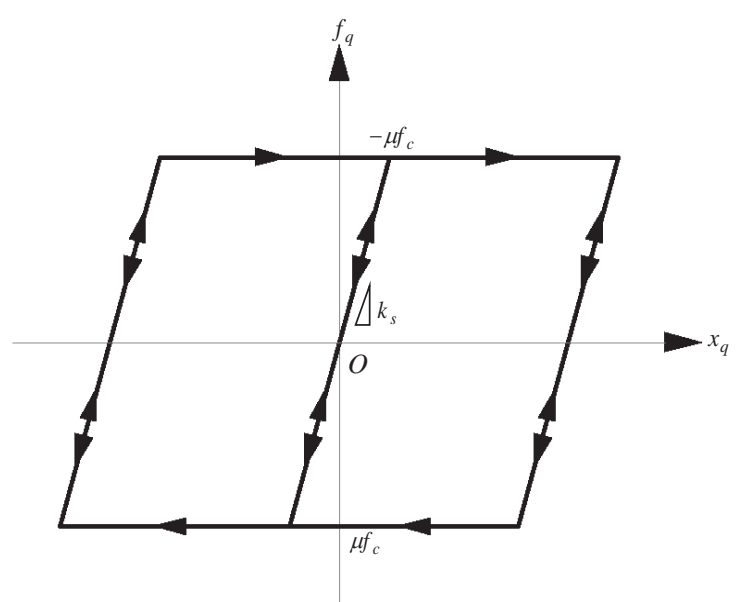

Fig. 5 Constitutive law of shear spring 


$$
\mathrm{f}_{\mathrm{q}}=\mathrm{h} \mu \mathrm{f}_{\mathrm{c}}+(1-\mathrm{h}) \mathrm{k}_{\mathrm{s}} \dot{x}_{\mathrm{q}}
$$

ここに、hはせん断ばねの状態を表す係数であり、せん断ばねがク ーロン摩擦の構成則を満たし続ける場合は $\mathrm{h}=1$ となり、満たさな い場合は $\mathrm{h}=0$ をとる。

式(4)，(13)より、次式のようにクーロン摩擦の構成則を直接組み 込んだ剛性方程式が得られる。

$$
\mathbf{p}=\mathbf{D}^{\top} \mathbf{C K D u}
$$

ここに、Cはせん断ばねの状態を考慮した係数行列であり、次式の ように表される。

$$
\mathbf{C}=\left[\begin{array}{ccc}
\mathbf{I}_{\mathrm{e}} & \mathbf{0} & \mathbf{0} \\
\mathbf{0} & \mathbf{I}_{\mathrm{c}} & \mathbf{0} \\
\mathbf{0} & \mathbf{B} & \mathbf{I}_{\mathrm{c}}-\mathbf{H}
\end{array}\right]
$$

ここに、

$$
\mathbf{B}=\left[\begin{array}{ccc}
h_{\mu} \mu_{1} & & \mathbf{0} \\
& \ddots & \\
\mathbf{0} & & h_{h} \mu_{\mathrm{n}}
\end{array}\right], \quad \mathbf{H}=\left[\begin{array}{lll}
h & & \mathbf{0} \\
& \ddots & \\
\mathbf{0} & & h_{h}
\end{array}\right]
$$

$\mathbf{I}_{\mathrm{e}}, \mathbf{I}_{\mathrm{c}}$ はそれぞれ $\mathrm{m}$ 次、 $\mathrm{n}$ 次の単位行列、Bは $\mathrm{h}$ と $\mu$ の積からな る $\mathrm{n}$ 次の対角行列、H は $\mathrm{h}$ からなる $\mathrm{n}$ 次の対角行列を示す。

式(14)を解くことにより、諸状態の変化率を得ることができる。 変位増分解析は、通常の変位増分解析手法のアルゴリズムに基づい て実行する。

変位増分解析の第 $\mathrm{N}$ ステップにおける $\mathrm{h}$ の設定方法は以下の通 りである。まず、すべてのせん断ばねについて、本来満たすべき構 成式に対応寸る $\mathrm{h}=0$ を初期值として設定し、剛性方程式を解く。

第 $\mathrm{N}$ ステップにおけるせん断ばねの状態がクーロン摩擦の構成則 を満たしていない場合 $\left(\left|f_{\mathrm{q}}^{(\mathrm{N})}\right|<\left|\mu \mathrm{f}_{\mathrm{c}}^{(\mathrm{N})}\right|\right)$ 、せん断ばねは弾性状態が続 くため、 $\mathrm{h}=0$ のままとする。せん断ばねの状態がクーロン摩擦の 構成則を満たしている場合 $\left(\left|f_{\mathrm{q}}^{(\mathrm{N})}\right|=\left|\mu \mathrm{f}_{\mathrm{c}}^{(\mathrm{N})}\right|\right)$ 、第 $\mathrm{N}+1$ ステップのせん 断ばねのばね力と最大摩擦力をそれぞれ求める。 $\left|\mathrm{f}_{\mathrm{q}}^{(\mathrm{N}+1)}\right|<\left|\mu \mathrm{f}_{\mathrm{c}}^{(\mathrm{N}+1)}\right|$ と 求められた場合、せん断ばね水弾性状態になるものと判定し、 $\mathrm{h}=0$ とする。 $\left|f_{a}^{(N+1)}\right| \geq\left|\mu f_{c}^{(N+1)}\right|$ と求められた場合、せん断ばねはクーロン 摩擦の構成則を満たし続けるものと判定し、 $\mathrm{h}=1$ とし、再び剛性 方程式を解く。すべてのせん断ばねについて、そのばねの状態と $\mathrm{h}$ の值が整合するまでこの手順を繰り返す。

この方法は繰り返し収束計算を必要としないため、計算回数は大 幅に減少することとなる。

式(14)に関して、せん断ばねについて、クーロン摩擦の構成則を 満たし続ける場合 $(h=1)$ は、剛性方程式の対称性が失われ、不静定 次数が減少することとなる。

Fig.1 のように骨組が一方向載荷を受けたときの仕口を例に挙げ る。このときの仕口の剛体 - ばねモデルを Fig. 7 に示す。el 及び $c 1$ 〜 $c 2$ はめり込みばね、 $q 1 \sim q 2$ はせん断ばねを表す。めり込みばね $c 1 \sim c 2$ は柱と貫の接触面に、 $\mathrm{e} 1$ は込栓接触面に配置する。 $\mathrm{d}_{1} \sim \mathrm{d}_{5}$ はばね配置位置の距離を表す。この剛体 - ばねモデルの変位を代表 する節点として点 $A, B$ を設ける。節点 B は込栓の位置である。また、 点 $A$ と点 $B$ は剛棒で接続されていることから、2 点の変位は従属関 係となり、2 自由度モデルとなる。

この仕口の剛体 - ばねモデルについて、節点力速度ベクトル $\mathbf{p}$ と 節点変位速度ベクトル $\mathbf{u}$ は次式のように表される。

$$
\mathbf{p}=\left\{\begin{array}{ll}
p_{x} & p_{\theta}
\end{array}\right\}^{\top}, \quad \mathbf{u}=\left\{\begin{array}{ll}
\dot{u} & \dot{\theta}
\end{array}\right\}^{\top}
$$

$\mathbf{x}$ と D次式のように表される。

$$
\mathbf{x}=\left\{\begin{array}{l}
x_{e 1} \\
x_{c 1} \\
x_{c 2} \\
x_{q 1} \\
x_{q 2}
\end{array}\right\}, \quad \mathbf{D}=\left[\begin{array}{cc}
1 & d_{1} \\
-1 & -\left(d_{1}-d_{2}\right) \\
1 & d_{1}+d_{3} \\
0 & d_{5} \\
0 & d_{4}
\end{array}\right]
$$

$\mathbf{f}$ と K は次式のように表される。

$$
f=\left\{\begin{array}{c}
f_{\mathrm{el}} \\
\mathrm{f}_{\mathrm{c} 1} \\
f_{\mathrm{c} 2} \\
\mathrm{f}_{\mathrm{q} 1} \\
f_{\mathrm{q} 2}
\end{array}\right\}, \quad \mathbf{K}=\left[\begin{array}{ccccc}
k_{\mathrm{el}} & 0 & 0 & 0 & 0 \\
0 & k_{\mathrm{c} 1} & 0 & 0 & 0 \\
0 & 0 & k_{\mathrm{c} 2} & 0 & 0 \\
0 & 0 & 0 & k_{\mathrm{q} 1} & 0 \\
0 & 0 & 0 & 0 & k_{\mathrm{q} 2}
\end{array}\right]
$$

せん断ばね $q 1$ のみクーロン摩擦の構成則を満たし続ける場合を 想定すると、式(15)は次式のように表される。

$$
\mathbf{C}=\left[\begin{array}{ccccc}
1 & 0 & 0 & 0 & 0 \\
0 & 1 & 0 & 0 & 0 \\
0 & 0 & 1 & 0 & 0 \\
0 & \mu 1 & 0 & 0 & 0 \\
0 & 0 & 0 & 0 & 1
\end{array}\right]
$$

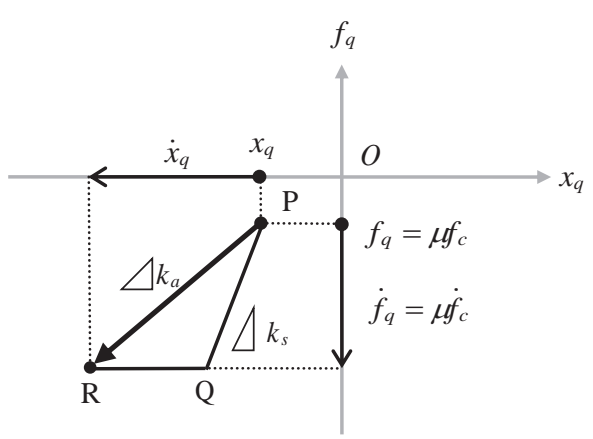

Fig. 6 Concept of apparent shear stiffness

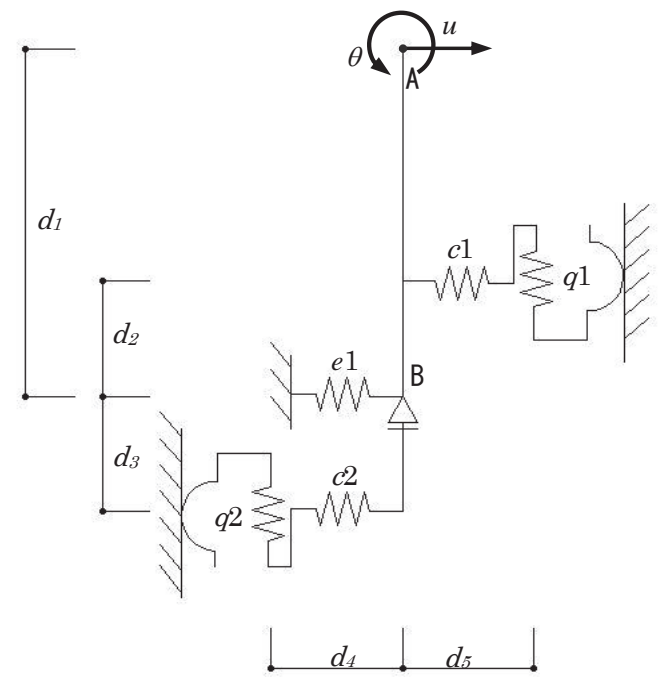

Fig. 7 Rigid body-spring model of joint 


\section{3. 貫込栓打ち仕口の繰り返し載荷実験及び弾塑性解析}

本論文で提案した解析法の妥当性を確認するために、Fig.7 のモ デルに対応するような仕口として柱と貫から構成される貫込栓打ち 形式の仕口（以降、貫込栓打ち仕口と称する）を対象とした繰り返 し載荷実験を実施し、実験結果のシミュレーションを行う。

\section{1 繰り返し載荷実験}

\section{1.1 試験体概要}

Fig.8 に試験体の詳細を示す。試験体は柱にほぞ穴を設け、そこ に貫を差し込み、込栓を打ち込んだ $\mathrm{T}$ 字型試験体である。樹種は柱 及び貫はスギ、込栓はカシである。2.1 節におけるモデル化の基本 仮定に対応するように、仕口の幅方向における摩擦による影響がで きるだけ排除できるように作製した。

\subsection{2 実験概要}

実験概要を Fig.9 に示す。本実験では試験体の柱部分を鉄板及び $\mathrm{H}$ 形鋼で挟み込み、反力フレームに設置し、ボルトを用いて固定す る。載荷方法について、デジタルジャッキを用いた変位制御の正負 交番繰り返し載荷とする。載荷サイクルは反転変形角 $\pm 1 / 400, \pm$ $1 / 200(\mathrm{rad})$ をそれぞれ 2 回、 $\pm 1 / 100 ， \pm 1 / 75 ， \pm 1 / 50(\mathrm{rad})$ をそれぞ れ 3 回繰り返す。その後 1 回のみ $\pm 1 / 30(\mathrm{rad})$ で繰り返したのち 0(rad)まで除荷する。測定方法について、荷重はロードセルを用い て計測する。変形角はレーザー変位計により計測された水平変位を 載荷点から込栓までの距離で除して評価する。

\subsection{3 実験結果}

実験結果として、復元力特性を Fig.10 に示す。履歴は木造仕口特 有のスリップ型を描いた。繰り返し履歴の回数が増えるにつれて、 立ち上がり勾配が低下している。これはめり込みによる残留塑性変 形が発生し、仕口に緩みが生じたことによるものと考えられる。

\section{2 弾塑性解析}

\section{2.1 解析概要}

貫込栓打ち仕口の解析モデルを Fig.11 に示す。これは Fig.7 を左 右対称に配置した解析モデルに相当する。図中の数字は節点番号、 括弧付き数字は部材番号を表す。節点 1 の水平変位 U 1 を変位制御す る変位増分解析を行う。

木材の材料定数を Table 1 に示す。縦圧縮ヤング係数 E 0 は JIS ${ }^{9)}$ に基づく縦圧縮試験により得る。横圧縮降伏ひずみ $\varepsilon_{\perp y}$ 及び第 2 剛 性に関するパラメータ $\alpha_{\perp}$ はJIS9)に基づく部分圧縮試験により得ら れた荷重 - 変位関係 $(\mathrm{PL} \sim \delta \mathrm{L}$ 関係)をバイリニア近似寸ることによ

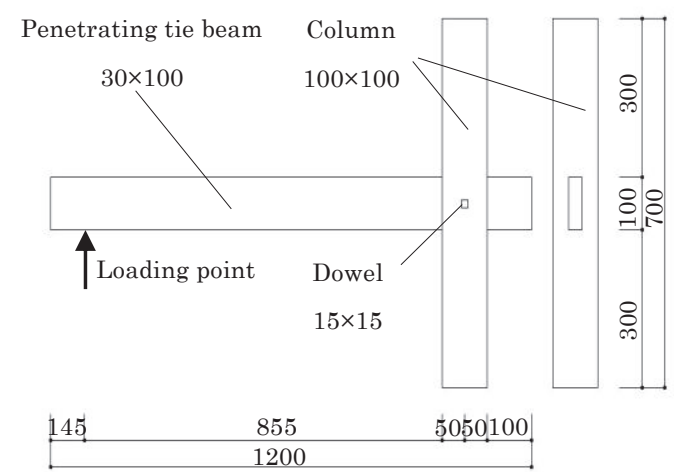

Fig. 8 Detail of Penetrating tie beam joint with dowel (unit : mm)

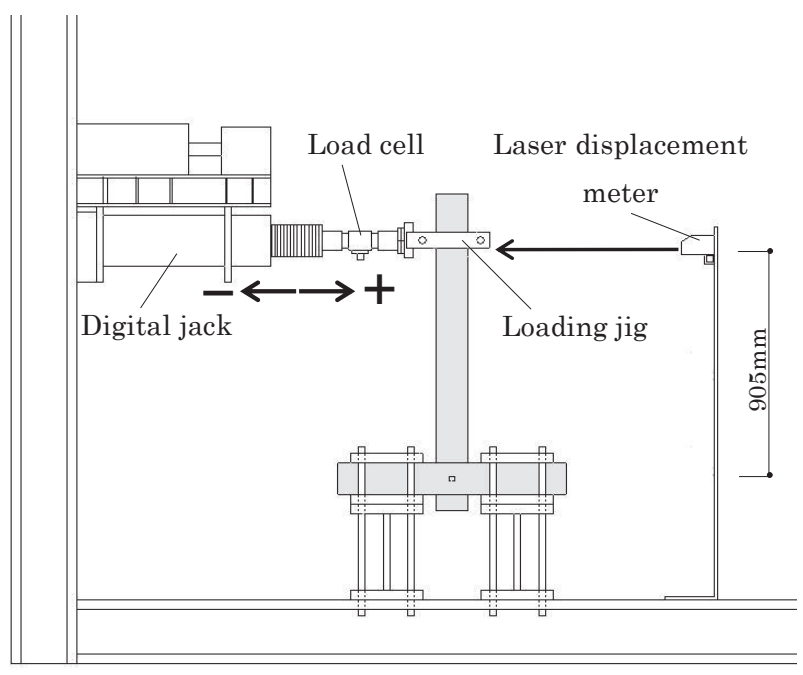

Fig. 9 Overview of experimental setup (Penetrating tie beam joint with dowel)

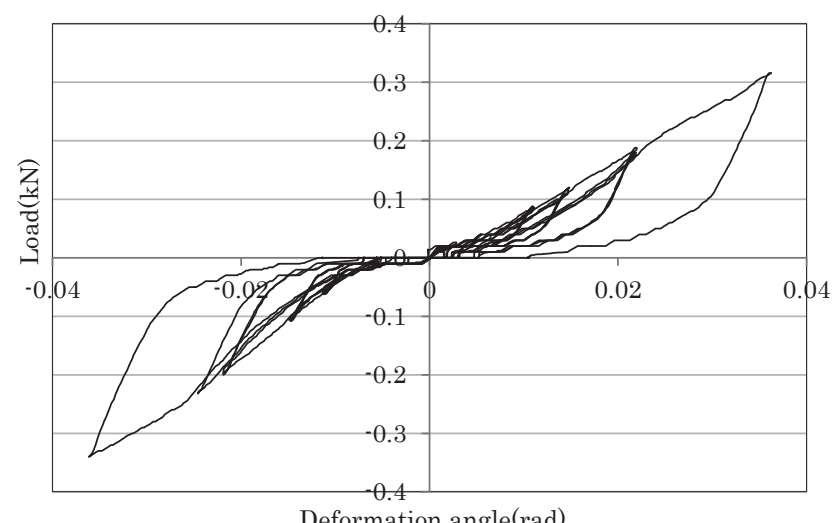

Fig. 10 Restoring force characteristics (Penetrating tie beam joint with dowel)

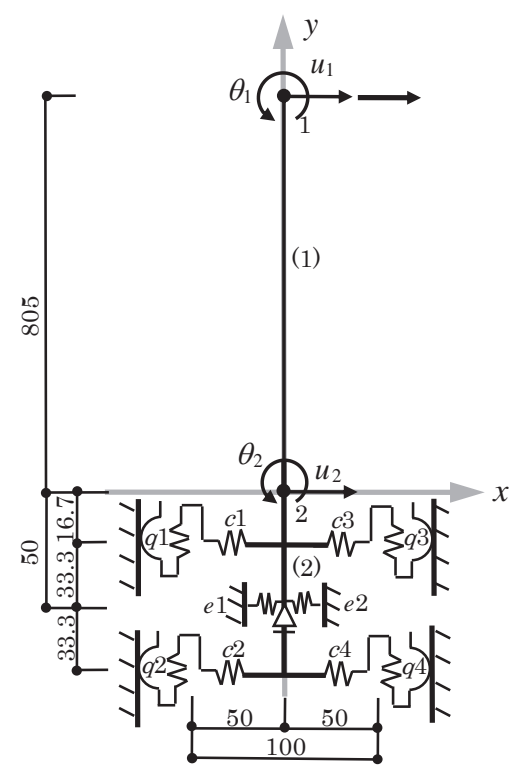

Fig. 11 Analysis model of penetrating tie beam joint with dowe I (unit: mm) 
り得る。部分圧縮試験の試験体を Fig. 12 に示す。第 1 勾配は次式に 示す等変位めり込み基準式 8) 基づく。

$$
\mathrm{PL}=\frac{\mathrm{xp}_{\mathrm{p}} \mathrm{C}_{\mathrm{x}} \mathrm{C}_{\mathrm{y}} \mathrm{E}_{\perp}}{\mathrm{Z}_{0}} \delta \mathrm{L}
$$

ここに、 $x_{p}$ は接触面の材軸方向長さ， $y_{p}$ は接触面の幅、 $z_{0}$ は材 厚、 $\mathrm{X}_{1}$ は余長部の長さ、 $\mathrm{C}_{\mathrm{x}}$ は䋊維方向の余長部のめりこみに関す る係数、Cy は幅方向の余長部のめりこみに関する係数を示す。試 験体寸法は $\mathrm{Xp}_{\mathrm{p}}=\mathrm{X}_{1}=\mathrm{y}_{\mathrm{p}}=\mathrm{Z}_{0}=30(\mathrm{~mm})$ であり、 $\mathrm{C}_{\mathrm{x}}=2.04$ 、 $\mathrm{C}_{\mathrm{y}}=1.0$ となる。第 1 勾配は横圧縮ヤング係数 $\mathrm{E}_{\perp}=\mathrm{E}_{0} / 50$ を用い た時、良い近似を示した。

めり込みばねについて、第 1 剛性 $\mathrm{k}_{1}$ は三角形変位めり込みの場合 は以下に示寸モーメント - 変形角関係式 $\left(\sum \mathrm{M} \sim \theta \text { 関係式 }\right)^{8}$ に基づ いて求める。

$$
\sum M=\frac{x_{p}^{3} y_{p} C_{y} E_{\perp} \theta}{Z_{0}}\left[\frac{1}{3}+\frac{1}{a_{e} X_{p}}\left(1-e^{-a e x_{1}}\right)\right]
$$

ここに、 $a_{e}$ は余長部の変形を定める係数を示す。

式(22)は三角形分布応力度の合力によるモーメントと余長部の応 力度の合力によるモーメントの和によって構成されている。本論文 ではこれら 2 つの合力の和がばね配置位置におけるばね力となるよ うにばね剛性 $k_{1}$ を求める。 $k_{1}$ は次式となる。

$$
\mathrm{k}_{1}=\frac{3}{2} \frac{\mathrm{x}_{\mathrm{p}}^{3} \mathrm{y}_{\mathrm{p}} \mathrm{C}_{\mathrm{y}} \mathrm{E}_{\perp}}{\mathrm{z}_{0}}\left[\frac{1}{2}+\frac{1}{\mathrm{aexp}_{\mathrm{e}}}\left(1-\mathrm{e}^{-\mathrm{aex}_{1}}\right)\right]
$$

降伏縮み Xcy はばね配置位置における材厚と横圧縮降伏ひずみ $\varepsilon \perp y$ との積により求める。

せん断弾性ばねの剛性 $\mathrm{k}_{\mathrm{s}}$ は材料構成則に基づく定量的な評価が 困難なため、めり込みばねの剛性が接触面積に依存することから、 文献 5)における提案のように $\mathrm{k}_{\mathrm{x}}$ は接触面積 $A\left(=\mathrm{xp} \times \mathrm{y}_{\mathrm{p}}\right)$ に比例 すると仮定して、次式で求めることとする。

$$
\mathrm{k}_{\mathrm{s}}=\beta \mathrm{A}
$$

$\beta$ については、文献 5) と同じ值を用いる。また、スギ - スギ間の摩 擦係数 $\mu$ の值は文献 10) より得た。

ae について、めり込み理論 ${ }^{8)}$ では $\mathrm{ae}=1.5 /$ Zo としている。この 值に基づいて求めためり込みばねのばね定数を用いて予備解析を行 ったところ、回転剛性を過大に評価してしまい、復元力が実験結果

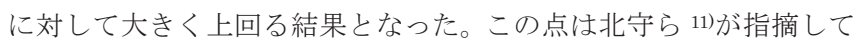
いる所である。北守ら ${ }^{11}$ は貫接合部の場合は余長部による影響を考 慮して $a_{e}=5.5 /$ zo を提案している。本章ではこの值を用いること とする。

貫込栓打ち仕口のめり込みばねの力学特性を Table 2、せん断ば ねの力学特性を Table 3 にそれぞれ示す。載荷サイクルは反転変形 角 $\pm 1 / 200 ， \pm 1 / 100 ， \pm 1 / 75 ， \pm 1 / 50 ， \pm 1 / 30(\mathrm{rad})$ をそれぞれ 1 回繰 り返すものとし、解析を行う。

\subsection{2 解析結果及び考察}

解析結果として、貫込栓打ち仕口の復元力特性を実験結果と合わ せて Fig.13 に示す。ただし、実験結果は載荷サイクル $\pm 1 / 400 ， \pm$ $1 / 200 ， \pm 1 / 100 ， \pm 1 / 75 ， \pm 1 / 50 ， \pm 1 / 30(\mathrm{rad})$ におけるそれぞれ 1 回目の履歴ループのみを取り出している。Fig.13より、実験結果と 解析結果は耐力及び剛性を含めた履歴ループの形状がそれぞれ概ね 一致している。このことから、本論文で提案した解析法の妥当性が 確認できる。また、実験結果では繰り返し履歴の回数が増えるにつ
Table 1 Material properties of wood (Penetrating tie beam joint with dowel)

\begin{tabular}{|c|c|}
\hline $\mathrm{E}_{0}\left(\times 10^{3}\left(\mathrm{~N} / \mathrm{mm}^{2}\right)\right)$ & 5.6 \\
\hline$\varepsilon_{\perp \mathrm{y}}$ & 0.01 \\
\hline$\alpha \perp$ & 0.1 \\
\hline$\beta\left(\mathrm{N} / \mathrm{mm}^{3}\right)$ & 11.4 \\
\hline$\mu$ & 0.54 \\
\hline
\end{tabular}

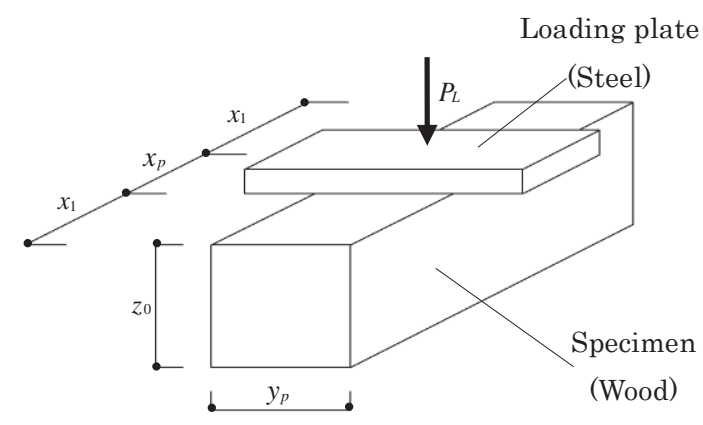

Fig. 12 Local compression test

Table 2 Mechanical properties of compression springs

(Penetrating tie beam joint with dowel) $\left(a_{e}=5.5 / z_{0}\right)$

\begin{tabular}{|c|c|c|c|c|}
\hline No. & Direction & $\begin{array}{c}\text { Coordinates } \\
(\mathrm{mm})\end{array}$ & $\begin{array}{c}\mathrm{k}_{1} \\
\left(\times 10^{3} \mathrm{~N} / \mathrm{mm}\right)\end{array}$ & $\begin{array}{c}\mathrm{Xcy}_{\mathrm{cy}} \\
(\mathrm{mm})\end{array}$ \\
\hline $\mathrm{e} 1$ & $\mathbf{X}$ & -50.0 & 1.01 & -1.00 \\
\hline $\mathrm{e} 2$ & $\mathbf{X}$ & -50.0 & 1.01 & -1.00 \\
\hline$c 1$ & $\mathbf{X}$ & -16.7 & 2.17 & -1.00 \\
\hline$c 2$ & $\mathbf{X}$ & -83.3 & 2.17 & -1.00 \\
\hline$c 3$ & $\mathbf{X}$ & -16.7 & 2.18 & -1.00 \\
\hline$c 4$ & $\mathbf{X}$ & -83.3 & 2.18 & -1.00 \\
\hline
\end{tabular}

Table 3 Mechanical properties of shear springs (Penetrating tie beam joint with dowel)

\begin{tabular}{|c|c|c|c|c|}
\hline No. & Direction & $\begin{array}{c}\text { Coordinates } \\
(\mathrm{mm})\end{array}$ & $\begin{array}{c}\mathrm{ks} \\
\left(\times 10^{3} \mathrm{~N} / \mathrm{mm}\right)\end{array}$ & $\begin{array}{c}\mathrm{A} \\
\left(\mathrm{mm}^{2}\right)\end{array}$ \\
\hline$q 1$ & $\mathrm{y}$ & -50.0 & 16.8 & 1500 \\
\hline$q 2$ & $\mathrm{y}$ & -50.0 & 16.8 & 1500 \\
\hline$q 3$ & $\mathrm{y}$ & 50.0 & 16.8 & 1500 \\
\hline$q 4$ & $\mathrm{y}$ & 50.0 & 16.8 & 1500 \\
\hline
\end{tabular}

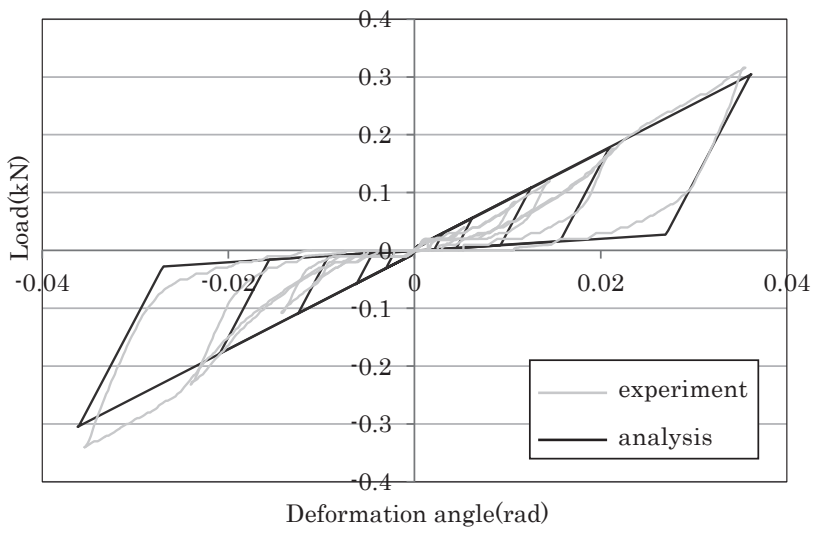

Fig. 13 Restoring force characteristics (Penetrating tie beam joint with dowel) (experiment vs. analysis) 


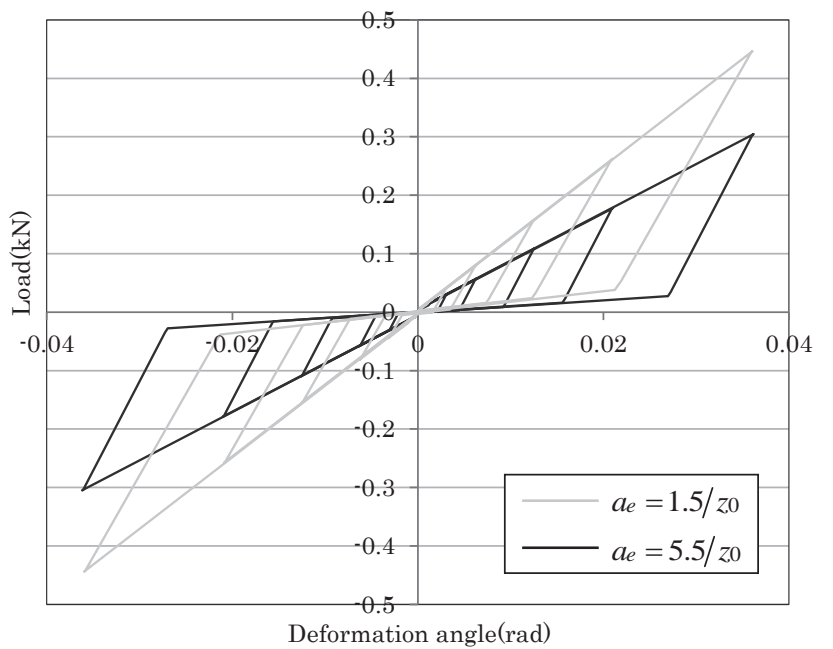

Fig. 14 Restoring force characteristics (Penetrating tie beam joint with dowel)

(analysis : $a_{e}=1.5 / z_{0}, \quad a_{e}=5.5 / z_{0}$ )

れて立ち上がり勾配が低下しているのに対して、解析結果における 剛性の変化は見られなかった。これは 1 つの接触面をバイリニア型 のばねモデル 1 つで置き換えるという単純なモデル化の方針に由来 寸るものであり、連続的な変化について表現できないためである。

参考として、 $a_{e}=1.5 / z_{0}$ とした場合の解析結果と $a_{e}=5.5 /$ zo とした場合の解析結果を合わせて Fig.14 に示す。復元力の值などの 定量的な評価に関しては剛性に関する適切な評価方法の確立が重要 であることが確認できる。

\section{4. 長ほぞ差し込栓打ち仕口の繰り返し載荷実験及び弾塑性解析}

本論文で提案した解析法の妥当性に加えてさらに有効性を確認す るために、文献 5)にて既に報告されている柱と差鴨居から構成され る長ほぞ差し込栓打ち形式の仕口（以降、長ほぞ差し込栓打ち仕口 と称する）を対象とした繰り返し載荷実験の結果のシミュレーショ ンを行う。

\section{1 繰り返し載荷実験 ${ }^{5)}$}

\subsection{1 試験体概要}

Fig. 15 に試験体及び変位の計測位置（ $\delta$ は変位計を意味する）を 示す。仕口の詳細を Fig.16に示す。樹種は差鴨居、柱はスギ、込栓、 鼻栓、楔はカシである。

\section{1.2 実験概要}

載荷方法について、変位制御の正負交番載荷とし、載荷はデジタル ジャッキが伸びる方向を正とする。載荷サイクルは反転変形角士 $1 / 600, \pm 1 / 450, \pm 1 / 300, \pm 1 / 200, \pm 1 / 150, \pm 1 / 100, \pm 1 / 75, \pm$ $1 / 50(\mathrm{rad})$ で、各サイクルの繰り返し回数は 3 回である。その後士 $1 / 15(\mathrm{rad})$ で 1 回のみ繰り返し載荷し、最後に正方向のみ $1 / 10(\mathrm{rad})$ まで載荷したのち $0(\mathrm{rad})$ まで除荷する。測定方法について、ロード セルで荷重を、変位計 1,2 で水平変位を、変位計 3,4 で仕口におけ る柱と差鴨居の相対変位を、変位計 5,6 でピン支点の浮き上がりを 計測した。変形角を評価する式を以下に示す。

$$
\text { 変形角 : } \quad \gamma=\left(\delta_{1}-\delta_{2}\right) / \mathrm{L}_{12}-\left(\delta_{5}-\delta_{6}\right) / \mathrm{L}_{56}
$$

$\delta \mathrm{i}$ : 変位計 $\mathrm{i}$ で測定した変位 $\mathrm{L}_{\mathrm{ij}}$ : 変位計 $\mathrm{i}, \mathrm{j}$ の測定位置間隔

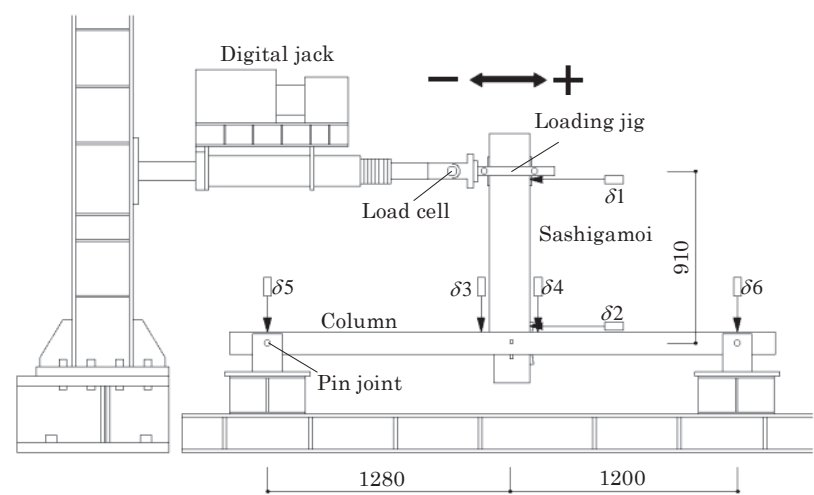

Fig. 15 Overview of experimental setup (unit: mm) (Mortise-tenon joint with dowel)

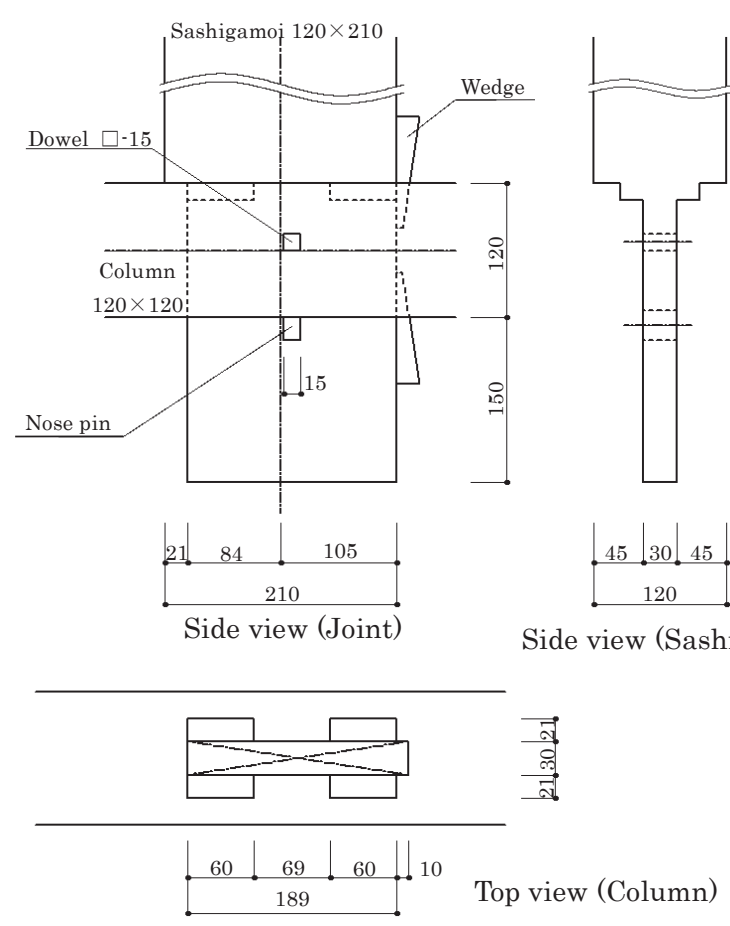

Fig. 16 Detail of Sashigamoi joint (unit:mm)

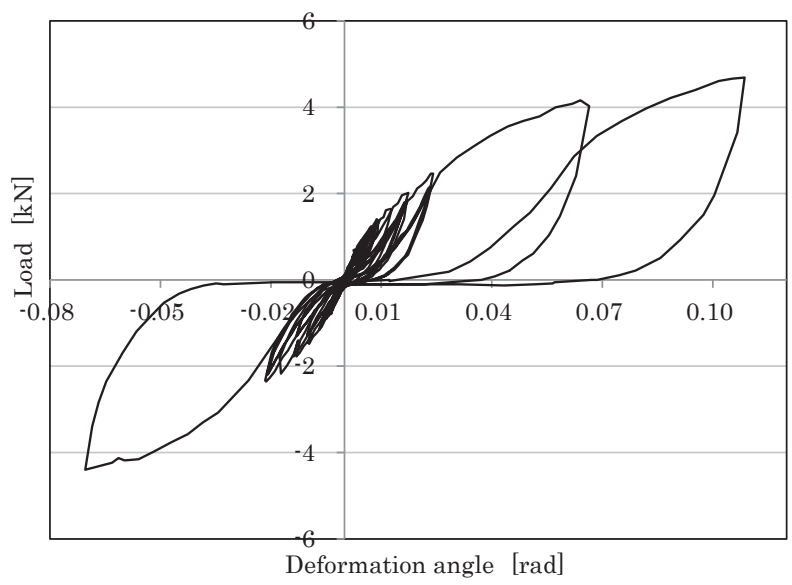

Fig. 17 Restoring force characteristic (Mortise-tenon joint with dowel) 


\subsection{3 実験結果}

載荷実験の結果として、復元力特性を Fig. 17 に示す。 $\pm 1 / 150(\mathrm{rad})$ サイクル以下の小変形領域では、 $2 、 3$ 回目の履歴ループは 1 回目の 履歴ループと同じ経路を辿り、 $\pm 1 / 150(\mathrm{rad})$ を超える大変形領域で は 1 回目の履歴ループにおいて過去に経験した最大変形までの履歴 は前サイクルの載荷過程における 2,3 回目の履歴ループと同じ経路 を辿った。繰り返し履歴の回数が増えるにつれて、立ち上がり勾配 が低下した。これはめり込みによる残留塑性変形によって仕口内部 のクリアランスや楔の緩みが生じたことによると考えられる。変形 角が大きくなるにつれて、載荷過程の剛性が徐々に低下した。この 剛性低下の主要な要因は、ほぞ及び胴付き接触面でのめり込みによ る局所的な塑性変形であると考えられる。仕口の変形については、 ほぞ及び胴付き接触面でのめり込みと楔の変形を確認したが、鼻栓 の曲げ破壊やほぞのせん断破壞等の終局状態には至らなかった。

\section{2 弾塑性解析}

\section{2.1 解析概要}

長ほぞ差し込栓打ち仕口の解析モデルを Fig.18に示す。Fig.18(a) は線材モデル、Fig.18 (b)は差鴨居仕口の剛体 - ばねモデルを示す。 Fig.18(a)の中の数字は節点番号、括弧付き数字は部材番号を表す。 節点 1 の水平変位 $U_{1}$ を変位制御する変位増分解析を行う。

木材の材料定数及びばね定数の算出方法は 3.2 節と同様である。 木材の材料定数を Table 4 に示す。

縦圧縮ヤング係数に対する横圧縮ヤング係数の比について、めり 込み理論 8)では $1 / 50$ としており、この值を用いて、予備解析を行っ たところ、復元力は実験結果の $1 / 2$ 程度となった。これは Fig. 16 に 示されるような仕口形状に対して楔等の影響を無視するなど比較的 単純なモデル化を行ったことや、仕口の幅方向における摩擦抵抗を 無視するなどという基本仮定に基づいていることが要因として考え られる。本章では、これらの影響を縦圧縮ヤング係数に対する横圧 縮ヤング係数の比をパラメータとして代表させることとして、この 值を $1 / 25$ と仮定して用いることとする。なお、 $a_{e}=1.5 /$ Zn $^{8)}$ とす る。

差鴨居仕口のめり込みばねの力学特性を Table 5、せん断ばねの 力学特性を Table 6 にそれぞれ示す。載荷サイクルは反転変形角土 $1 / 150 ， \pm 1 / 50 ， \pm 1 / 15 ，+1 / 10(\mathrm{rad})$ をそれぞれ 1 回繰り返すものと

し、解析を行う。

\section{2.2 解析結果及び考察}

解析結果として、長ほぞ差し込栓打ち仕口の復元力特性を実験結 果と合わせて Fig.19 に示す。ただし、実験結果は載荷サイクル士 $1 / 150 ， \pm 1 / 50 ， \pm 1 / 15 ， \pm 1 / 10(\mathrm{rad})$ におけるそれぞれ 1 回目の履歴 ループのみを取り出している。Fig.19より実験結果及び解析結果は 耐力及び岡性を含めた履歴ループの形状がそれぞれ概ね一致するこ ととなった。このことから、本論文で提案した解析法の妥当性が確 認できる。また、両者の解析を行う上での設定パラメータは同一と しており、Fig.19の解析結果は文献 5)で提案された解析法を用いた 解析結果とわずかな誤差が生じるものの、一致する結果が得られた。 文献 5)で提案された解析法には収束判定条件が必要となり、せん断 ばねのばね力と最大摩擦力の絶対值の差が微小值 $\Delta$ 以内となるま で繰り返し収束計算を行っている。その結果、収束計算に由来する 程度の誤差が生じることとなる。本論文で提案する解析法ではこの

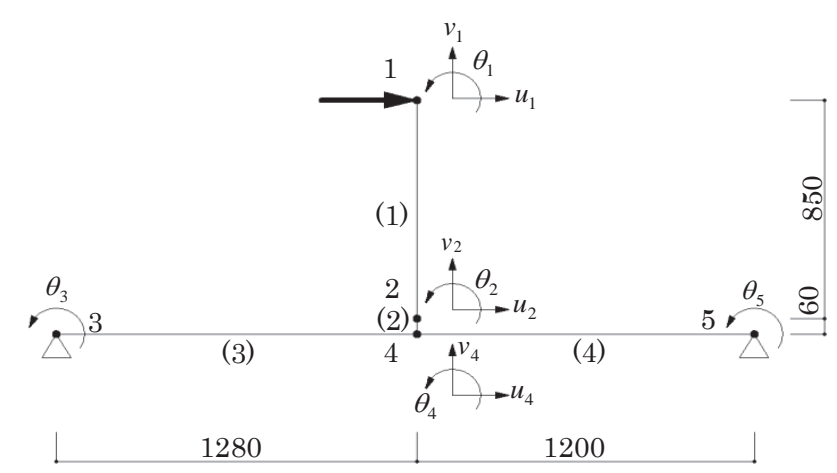

(a) Wire frame model (unit: $\mathrm{mm}$ )

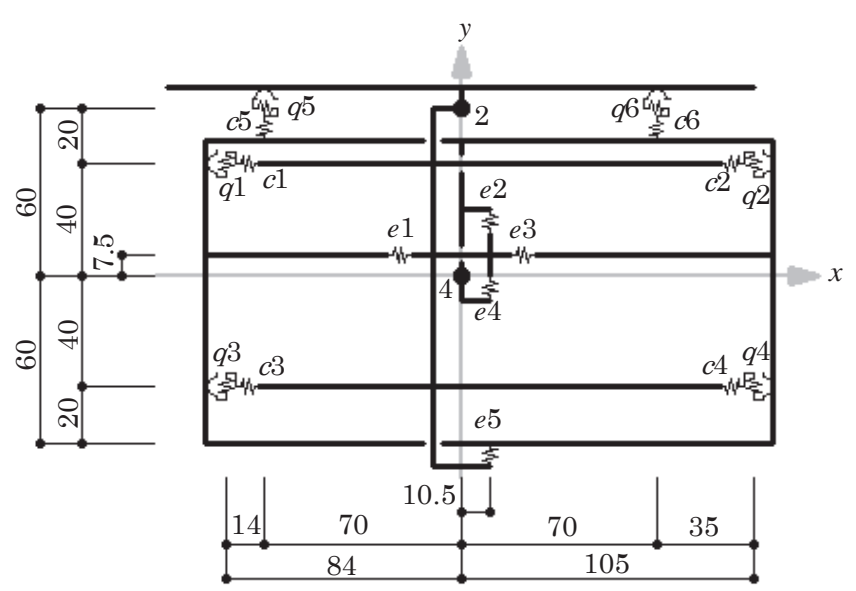

(b) Rigid body-spring model (unit: $\mathrm{mm}$ )

Fig. 18 Analysis model of mortise-tenon joint with dowel

Table 4 Material properties of wood

(Mortise-tenon joint with dowel)

\begin{tabular}{|c|c|}
\hline $\mathrm{E}_{0}\left(\times 10^{3}\left(\mathrm{~N} / \mathrm{mm}^{2}\right)\right)$ & 7.4 \\
\hline$\varepsilon_{\perp \mathrm{y}}$ & 0.01 \\
\hline$\alpha_{\perp}$ & 0.1 \\
\hline$\beta\left(\mathrm{N} / \mathrm{mm}^{3}\right)$ & 11.4 \\
\hline$\mu$ & 0.54 \\
\hline
\end{tabular}

Table 5 Mechanical properties of compression springs (Mortise-tenon joint with dowel) $\left(E_{\perp}=E_{0} / 25\right)$

\begin{tabular}{|c|c|c|c|c|}
\hline No. & Direction & $\begin{array}{c}\text { Coordinates } \\
(\mathrm{mm})\end{array}$ & $\begin{array}{c}\mathrm{k}_{1} \\
\left(\times 10^{3} \mathrm{~N} / \mathrm{mm}\right)\end{array}$ & $\begin{array}{c}\mathrm{X}_{\mathrm{cy}} \\
(\mathrm{mm})\end{array}$ \\
\hline $\mathrm{e} 1$ & $\mathrm{X}$ & 7.5 & 1.53 & -0.87 \\
\hline $\mathrm{e} 2$ & $\mathrm{y}$ & 10.5 & 8.88 & -0.45 \\
\hline $\mathrm{e} 3$ & $\mathrm{X}$ & 7.5 & 1.53 & -0.87 \\
\hline $\mathrm{e} 4$ & $\mathrm{y}$ & 10.5 & 6.66 & -0.60 \\
\hline $\mathrm{e} 5$ & $\mathrm{y}$ & 10.5 & 6.66 & -0.60 \\
\hline$c 1$ & $\mathrm{X}$ & 40.0 & 10.06 & -1.89 \\
\hline$c 2$ & $\mathrm{X}$ & 40.0 & 10.06 & -1.89 \\
\hline$c 3$ & $\mathrm{X}$ & -40.0 & 8.29 & -1.89 \\
\hline$c 4$ & $\mathrm{X}$ & -40.0 & 8.29 & -1.89 \\
\hline$c 5$ & $\mathrm{y}$ & -70.0 & 22.03 & -1.20 \\
\hline$c 6$ & $\mathrm{y}$ & 70.0 & 22.03 & -1.20 \\
\hline
\end{tabular}


Table 6 Mechanical properties of shear springs

(Mortise-tenon joint with dowel)

\begin{tabular}{|c|c|c|c|c|}
\hline No. & Direction & $\begin{array}{c}\text { Coordinates } \\
(\mathrm{mm})\end{array}$ & $\begin{array}{c}\mathrm{ks} \\
\left(\times 10^{3} \mathrm{~N} / \mathrm{mm}\right)\end{array}$ & $\begin{array}{c}\mathrm{A} \\
\left(\mathrm{mm}^{2}\right)\end{array}$ \\
\hline$q 1$ & $\mathrm{y}$ & -84.0 & 20.52 & 1800 \\
\hline$q 2$ & $\mathrm{y}$ & 105.0 & 20.52 & 1800 \\
\hline$q 3$ & $\mathrm{y}$ & -84.0 & 20.52 & 1800 \\
\hline$q 4$ & $\mathrm{y}$ & 105.0 & 20.52 & 1800 \\
\hline$q 5$ & $\mathrm{X}$ & 60.0 & 57.46 & 5040 \\
\hline$q 6$ & $\mathrm{X}$ & 60.0 & 57.46 & 5040 \\
\hline
\end{tabular}

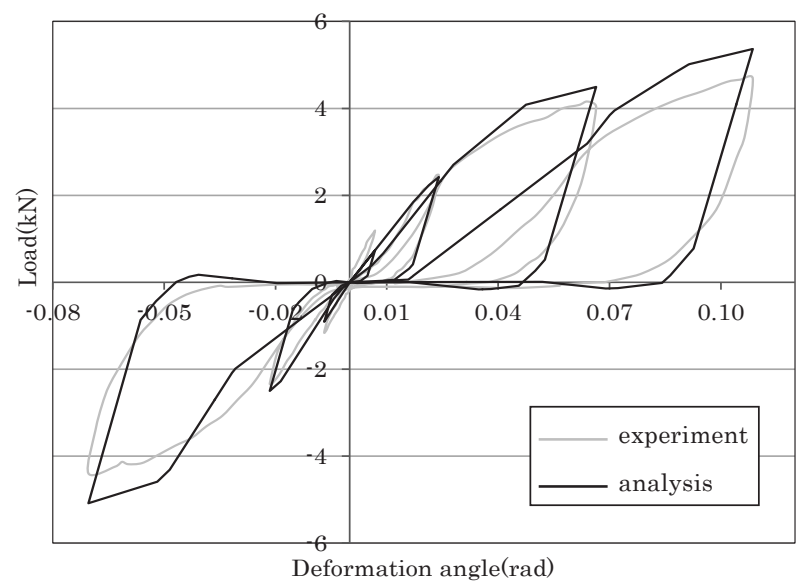

Fig. 19 Restoring force characteristics

(Mortise-tenon joint with dowel)

(experiment vs. analysis)

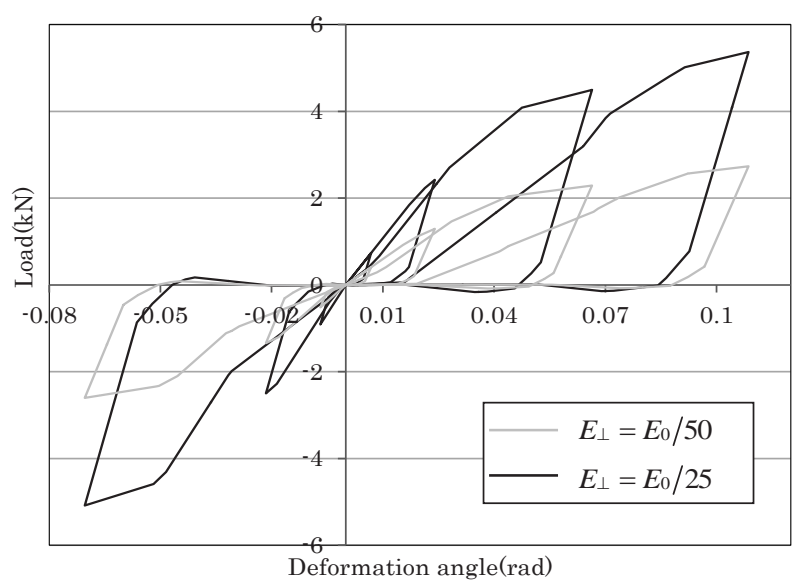

Fig. 20 Restoring force characteristics (Mortise-tenon joint with dowel)

(analysis : $E_{\perp}=E_{0} / 50, E_{\perp}=E_{0} / 25$ )

意味の誤差が生じない。

参考值ではあるが、反転変形角+1/10( $\mathrm{rad})$ における復元力を比較 すると、差は $0.5 \%$ 程度となった。また、計算回数を比較すると約 $1 / 200$ と大幅に低減する結果が得られた。従って、本論文で提案し た解析法は効率性が高いものであることが確認できた。

参考として、 $E_{\perp}=E_{0} / 25$ とした場合の解析結果と $E_{\perp}=E_{0} / 50$ と した場合の解析結果を合わせて Fig. 20 に示寸。貫込栓打ち仕口につ いての考察と同様に、剛性に関する適切な評価方法の確立が重要で

\section{あることが確認できる。}

本論文では、めり込み理論 ${ }^{8)}$ に基づいて復元力特性を評価した。 ここでは $E_{\perp} / E_{0}$ と $a_{e}$ の 2 つをパラメータとして用いており、 $\mathrm{E}_{\perp} / \mathrm{E}_{0}=1 / 50 、 \mathrm{a}_{\mathrm{e}}=1.5 / \mathrm{Z}_{0}$ が基準の值である。

貫込栓打ち仕口では、 $E_{\perp} / E_{0}=1 / 50 、 a_{e}=5.5 /$ zo を用いて解析 を行ったところ、復元力特性において解析結果と実験結果は良い対 応を示した。この要因としては、モデル化の基本仮定に対応するよ うに仕口の幅方向における摩擦による影響ができるだけ排除できる ように試験体を作製したこと、貫込栓打ち仕口は両側三角形変位め り込みの荷重状態であり、片側での三角形変位めり込みによる応力 が偶力をな寸反対側の三角形変位めり込み部分へと対称に流れるこ とにより、余長部が短くなったこと、その結果、接触面における圧 縮応力度分布の重心位置は三角形分布応力度の合力作用位置に近づ き、仮定したばね配置位置が良い近似となったこと等が考えられる。

一方、長ほぞ差し込栓打ち仕口では、 $\mathrm{E}_{\perp} / \mathrm{E}_{0}=1 / 25 、 \mathrm{a}_{\mathrm{e}}=1.5 / \mathrm{z} 0$ を用いて解析を行ったところ、復元力特性において解析結果と実験 結果は良い対応を示した。この要因としては、複雑な仕口形状に対 してその解析モデルは比較的単純なものであったが、実際には楔や 襟輪等が影響していたこと、鼻栓や楔等の打ち込みによる初期応力 が発生していたこと、仕口の幅方向における摩擦が発生していたこ と等が考えられる。

\section{5. まとめ}

伝統木造仕口を対象として、繰り返し載荷時の履歴特性を解析的 に評価することを目的とし、クーロンスライダー付きばねモデルを 用いた新たな変位増分解析法を提案した。本論文で得られた成果は 以下のとおりである。

（1）仕口内部の接触面において、接触面に対して平行方向の抵抗に ついて、クーロン摩擦の構成則を直接剛性方程式に組夕込む方法 を導入した。

（2）貫込栓打ち仕口及び長ほぞ差し込栓打ち仕口を対象とした繰り 返し載荷実験の結果に対して、提案した解析法に基づく変位増分 解析を行い、実験結果のシミュレーションをそれぞれ行った。そ れぞれの実験結果と解析結果は良い対応を示しており、本論文で 提案した解析法の妥当性を確認することができた。ただし、復元 力の值などの定量的な評価に関してはめり込み剛性の算出方法や ばねのモデル化などについて適切な評価方法の確立が重要であっ て、更なる検討が必要であり、今後の課題である。

（3）長ほぞ差し込栓打ち仕口について、本論文で提案した解析法に よる解析結果は文献 5)で提案された解析法を用いた解析結果と わずかな誤差が生じるものの、一致する結果が得られた。この誤 差は文献 5)で提案された解析法における収束判定条件に由来す るもので、本論文で提案する解析法ではこの意味の誤差が生じな い。また、計算回数は文献 5)で提案された解析法に比べて大幅に 低減した。これにより、本論文で提案した解析法は効率性が高い ものであることが確認できた。

\section{参考文献}

1) Funasaka, Y. and Nishimura, T. : A Simplified Mechanical Model Considered Local Deformation in Mortise-tenon Joints, Summaries of Technical Papers of Annual Meeting, Architectural Institute of Japan, 
C-1, pp.325-326, 2011.8 (in Japanese)

2) Morisako, K., Miyake, Y. and Kitao, S. : Hysteresis Model for Column-Nuki Connection of Traditional Timber Frame Based on Cyclic Loading Tests, Journal of Structural Engineering, Vol.51B, pp.503-512, 2005.3 (in Japanese)

3) Lee, D., Araki, Y., Endo, T., Yoshida, N. and Uetani, K. : Estimation of Semi-Rigid Characteristics for Column-Nuki Joints of Traditional Timber Architecture Based on Local Compression Experiments, Journal of Structural and Construction Engineering (Transactions of AIJ), Vol.73, No.631, pp.1577-1584, 2008.9 (in Japanese)

4) Nishikida, K., Yao, S. and Masui, T. : Analysis of Wooden Frame Used Joints Model Considered of Pullout and Compressive Strain Inclined to the Grain, Summaries of Technical Papers of Annual Meeting, Architectural Institute of Japan, C-1, pp.81-82, 2010.9 (in Japanese)

5) Masui, T., Nishikida, K. and Takagi, T. : Elasto-Plastic Analysis of Mortise-Tenon Joint with Dowel Subjected to Cyclic Loading, Journal of Structural and Construction Engineering (Transactions of AIJ), Vol.78, No.686, pp.753-762, 2013.4 (in Japanese)

6) Suganuma, N. and Masui, T. : Elasto-Plastic Analysis Method of Wooden Joint Considering Compressive Strain Inclined to Gain and Friction, Summaries of Technical Papers of Annual Meeting, Architectural Institute of Japan, C-1, pp.287-288, 2016.8 (in Japanese)

7) Inayama, M. : Study on Elastic Deformation Perpendicular to the Grain in Wood, Doctorate Thesis of the University of Tokyo, 1991.12 (in Japanese)

8) Fundamental Theory of Timber Engineering : AIJ, Maruzen Publishing, 2010(in Japanese)

9) Japanese Standards Association : Methods of Test for Woods (JIS Z2101), 2009 (in Japanese)

10) Forestry and Forest Products Research Institute : Mokuzai Kogyo Handbook, Maruzen Publishing, 2004 (in Japanese) (独)森林総合研究所 : 木材工業ハンドブック, 丸善(株), 2004

11) Kitamori, A., Mori, T., Kataoka, Y. and Komatsu, K. : Effect of Additional Length on Partial Compression Perpendicular to the Grain of Wood, Journal of Structural and Construction Engineering (Transactions of AIJ), Vol.74, No.642, pp.1477-1485, 2009.8 (in Japanese) 


\section{ELASTO-PLASTIC ANALYSIS OF JOINTS IN TRADITIONAL TIMBER FRAMES SUBJECTED TO CYCLIC LOADING}

Takeshi MASUI* and Nobuaki SUGANUMA**

* Prof., Dept. of Architecture, Faculty of Environmental and Urban Eng., Kansai Univ., Dr.Eng.

** Grad. Student, Graduate School of Science and Engineering, Kansai Univ.

Appropriate evaluation of the structural characteristics of joints is necessary in order to understand their horizontal resistance characteristics of traditional timber frames. For this purpose, it is important to create a simple joint model that takes into account hysteresis when the joint is subjected to cyclic loading, and to establish a suitable analysis method.

We have developed a spring model that considers compressive strain inclined to the grain in addition to the friction characteristics of the wood in a joint, and we have proposed an incremental displacement analysis method based on that model. The model considers resistive components at contact surfaces inside the joint by decomposing them into directions perpendicular and parallel to the contact surface. We represented the resistance perpendicular to the contact surface using compression springs and assumed a slip-bilinear constitutive law. We represented the resistance parallel to the contact surface using shear elastic springs and Coulomb's sliders. When the joint deforms, the spring force due to compressive strain inclined to the grain changes, and so the maximum friction force also changes. The shear springs must also satisfy the constitutive law with respect to the changing spring force due to compressive strain inclined to the grain. In the past, we introduced the concept of an apparent shear stiffness with regard to the shear springs. Using this method, we found that the apparent shear stiffness does not depend on the shear elastic spring stiffness. This method required an iterative calculation in order to derive the apparent shear stiffness. Consequently, there is a problem when dealing with complicated joint shapes in that there is an increase in the number of contact surfaces and spring models, so that the number of iterations required for the calculation to converge also increases.

In the present article, to solve this problem, we introduce a method of incorporating the constitutive law of Coulomb's friction for the shear spring directly into the stiffness equation. Fundamentally, the spring force rate for the shear spring depends on the elastic spring stiffness. If the shear spring continues to satisfy the constitutive law of Coulomb's friction as the joint deforms, the spring force rate for the shear spring must continue to satisfy the maximum friction force. Incorporating these relationships directly into the stiffness equation and solving the equation makes it possible to obtain the rate of change of various state variables. If the shear spring continues to satisfy the constitutive law of Coulomb's friction, the symmetry of the stiffness equation is lost and the degree of indeterminacy decreases.

We conducted a cyclic loading experiment on a joint with a dowel in a construction comprising a column and a penetrating tie beam. The loading method was displacement-controlled repeated and reversed cyclic loading using a digital jack. The experimental results revealed restoring force characteristics, with slip-type hysteresis specific to wooden joints.

We carried out an incremental displacement analysis based on the proposed method, and performed a simulation of the results of a loading experiment on a penetrating tie beam joint with a dowel and a mortise-tenon joint with a dowel. We compared the experimental and analysis results, and confirmed that the shapes of the hysteresis loops for strength and stiffness were generally consistent. When we compared the results of the present analysis with those obtained using the previous analysis method, they were the same. However, the number of calculations was drastically reduced using the proposed analysis method. These findings confirm the high validity and efficiency of the analysis method proposed in this article. 